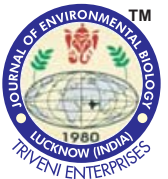

\title{
Characterization of plant growth promoting rhizobia from root nodule of Mimosa pudica grown in Assam, India
}

Authors Info

B. Singha ${ }^{1}$, P. B. Mazumder ${ }^{1 *}$ and P. Pandey

'Department of Biotechnology, Assam University,

Silchar-788 011, India

${ }^{2}$ Department of Microbiology,

Assam University,

Silchar-788 011, India

${ }^{*}$ Corresponding Author Email : pbmazumder65@gmail.com

Key words

16S rDNA,

Burkholderia,

Mimosa pudica,

PCR-RFLP, Rhizobia,

Publication Info

Paper received: 08.01.2016

Revised received : 23.05 .2016

Re-revised received : 30.09 .2016

Accepted:06.10.2016

\section{Abstract}

Aim: Rhizobia are diverse group of soil microorganisms that can form nodule in the roots of leguminous plants and fixes atmospheric nitrogen. In the present study, an attempt was made to characterize the plant growth promoting rhizobia from root nodules of Mimosa pudica grown in Assam.

Methodology: The bacterial isolates were investigated for their phenotypic features. Plant growth promoting abilities of the isolates were determined by conducting different tests. Genotypic characterization of the isolates was carried out by $16 \mathrm{~S}$ rDNA PCR-RFLP and $16 \mathrm{~S}$ rDNA gene sequencing. Symbiotic efficiency of the isolates was determined by nodulation test.

Results: The isolates showed similarity in colony morphology, shape and Gram staining, but showed variation in biochemical features. Most of the isolates produced indole acetic acid, ammonia and solubilized inorganic phosphate. Dendrogram based on PCRRFLP analysis of $16 \mathrm{~S}$ rDNA gene revealed significant diversity among the isolates. Phylogenetic analysis of the isolates, based on $16 \mathrm{~S}$ rDNA gene sequences, revealed that SMP2, HMP1 and DMP2 isolates were closely related to Burkholderia mimosarum PAS44, while KMP1 was closely related to Mesorhizobium loti MAFF303099.

Interpretation: The present study revealed that bacterial strains from Burkholderia genera were the major symbionts of Mimosa pudica grown in Assam. The isolates obtained in the present study possesed plant growth promoting abilities and could be used as a potent inoculants in future.

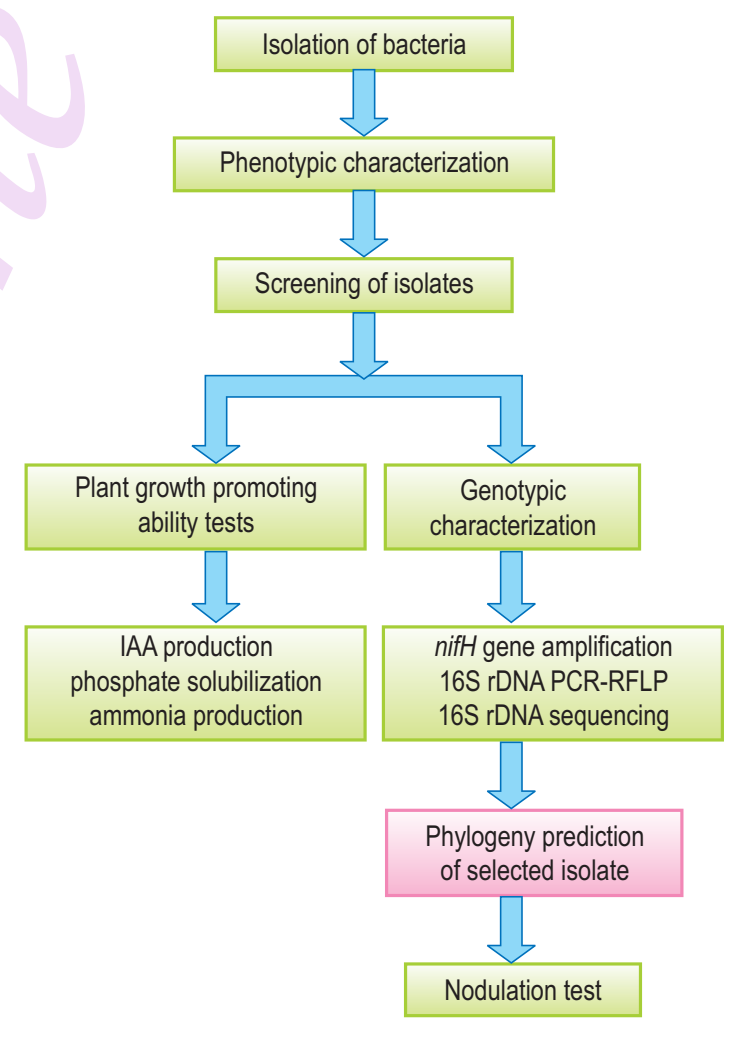




\section{Introduction}

Nitrogen is an essential nutrient for all living organisms. It is required for synthesizing amino acids, proteins, nucleic acids and other nitrogen-containing compounds necessary for life. In the last few decades, extensive use of chemical fertilizers in agriculture for supplying nitrogen to plants has resulted in hazardous effects to plants, animals and environment. Biological nitrogen fixation is a process in which inert nitrogen is converted to ammonia, thus reducing the requirement of nitrogenous fertilizers (Dilworth et al., 1969). Rhizobia are one of the best examples of biological nitrogen fixer. They form nodules in the roots of leguminous plants and fix atmospheric nitrogen. In addition to nitrogen fixation, rhizobia are well known for different plant growth promoting activities which include production of indole acetic acid (IAA), siderophore and ammonia, solubilization of inorganic phosphate, etc. (Deshwal et al., 2003). Rhizobialegume symbiosis is influenced by different factors which include soil $\mathrm{pH}$, soil salinity, soil moisture and extreme temperatures. Thus, identification of indigenous plant growth promoting and stress tolerant strain can serve as a better rhizobial inoculants for field application in agriculture.

Rhizobial diversity has been studied based on their cultural and morphological characteristics. However, in recent years with the availability of advanced PCR-based genotyping methods studies have revealed the presence of diverse rhizobial strains in root nodules of different leguminous plants. Earlier, it was believed that legumes can form nitrogen fixing symbiosis only with the members of alpha-rhizobia such as Rhizobium, Sinorhizobium, Azorhizobium, Mesorhizobium, Bradyrhizobium. However, Chen et al. (2001) reported the presence of betarhizobia, Ralstonia taiwanensis in the root nodules of Mimosa pudica and Mimosa diplotricha in Taiwan.

Mimosa pudica Linn. was believed to be originated in America. It is used as green manure, fodder crop and as herbal medicine in the treatment of various ailments including diarrhea, dysentery and various urogenital infections from time immemorial (Ahmad et al., 2012; Liu et al., 2012). Like other species, M. pudica preferentially interacts with the rhizobia belonging to betaproteobacteria (Chen et al., 2003). The beta-proteobacteria known to nodulate $M$. pudica mostly includes several Burkholderia and Cupriavidus (Liu et al., 2011). Assam lies at $89^{\circ} 42^{\prime}$ to $96^{\circ} \mathrm{E}$ longitude and $24^{\circ} 8^{\prime}$ to $28^{\circ} 2^{\prime} \mathrm{N}$ latitude in the north eastern part of India and it harbors numerous types of flora and fauna. The present study aimed to characterize the diversity of indigenous rhizobia associated with root nodules of $M$. pudica from different regions of Assam in order to select efficient plant growth promoting strains that can be useful for future application.

\section{Materials and Methods}

Collection of samples : Fresh root nodules were collected from M. pudica plants. Nodules were then surface sterilized, crushed in sterile distilled water and streaked on Yeast Extract Manitol Agar plates and incubated at $28^{\circ} \mathrm{C}$ for $3-5$ day (Vincent et al., 1970). In order to compare the phenotypic and genotypic traits of the isolates with reference strains, Rhizobium leguminosarum MTCC-99, Mesorhizobium thiogangeticum MTCC-7001, Bradyrhizobium japonicum MTCC-120 and Burkholderia cepacia MTCC-4684 were obtained from Institute of Microbial Technology (IMTECH), Chandigarh.

Phenotypic characterization: After an incubation period of three days at $28^{\circ} \mathrm{C}$ on yeast extract mannitol agar plate, individual colonies were observed for their size, colour, shape and Gram staining (Vincent et al., 1970). The isolates were assessed for eight different biochemical characteristics as per Bergey's Manual of Determinative Bacteriology by following standard procedure (Holt et al., 1994). For determining the ability of the isolates to grow in high salt concentration and acidic $\mathrm{pH}$, the isolates were streaked on three different YEMA plates adjusted with three different concentration $(1.0 \%, 2.0 \%$ and $3.0 \%)$ of $\mathrm{NaCl}$ (Romdhane et al., 2006) and three different pH $(4.0,5.0,6.0)$ (Kucuk et al., 2006). Growth of isolates on standard YEMA media (pH-7.0; $\mathrm{NaCl}-0.1 \%)$ was used as control.

Plant growth promoting ability of the isolates: The ability of the isolates to solubilize inorganic phosphate was evaluated by spotting the isolates on Pikovskya's agar plates (Pikovskaya, 1948). The efficiency of the isolates was expressed in terms of Phosphate Solubilization Efficiency (PSE). The isolates were tested for their production of IAA as described by Dubey and Maheshwari (2010). The amount of IAA produced was determined by comparing the data with a standard graph prepared by measuring the O.D. with different concentration of IAA (Gordon and Weber, 1951). The production of ammonia was determined by the method described by Kumar et al. (2012).

PCR amplification of nifH gene: Genomic DNA was extracted using standard phenol-chloroform extraction procedure (Sambrook et al., 1989). PCR amplification of nifH gene was carried with primers zehrf-5'TGCGACCCAAAAGCAGA3' and zehr-5'AAAGCCATCATCTCACC3' (Zehr and McReynolds, 1989). Amplification was performed with a total volume of $50 \mu \mathrm{l}$ containing $1 \mu$ l of genomic DNA(30 ng), $2.5 \mu$ of dNTP $(2.5 \mathrm{mM}), 1$ $\mu$ lof each primer ( $100 \mathrm{pmol}), 5 \mu$ of PCR buffer $(10 \mathrm{x}), 0.5 \mu \mathrm{l}$ of Taq polymerase $(1.5 \mathrm{U})$ and $40 \mu \mathrm{l}$ of nuclease free water. The reaction conditions were, initial denaturation at $95{ }^{\circ} \mathrm{C}$ for $5 \mathrm{~min}$, denaturation at $94^{\circ} \mathrm{C}$ for $30 \mathrm{sec}$, annealing at $58^{\circ} \mathrm{C}$ for $30 \mathrm{sec}$, extension at $72{ }^{\circ} \mathrm{C}$ for $45 \mathrm{sec}$ for 30 cycles and then final extension at $72^{\circ} \mathrm{C}$ for $7 \mathrm{~min}$. Amplified products were resolved on $1.5 \%$ agarose gel and documented in BIORAD gel documentation system.

PCR-RFLP analysis of $16 S$ rDNA: PCR amplification of $16 S$ rDNA gene was carried out by universal primers $27 f-$ 5'AGAGTTTGATCATGGCTCAG3' and 1492r- 
5'ACGGATACCTTGTTTACGACTT3' (Weisburg et al., 1991). Composition of PCR reaction mixture was similar to nifH gene. Amplifications were carried out with the following temperature profile: 5 min at $95^{\circ} \mathrm{C}$ followed by 30 cycles of denaturation at 94 ${ }^{\circ} \mathrm{C}$ for $1 \mathrm{~min}$, annealing at $55^{\circ} \mathrm{C}$ for $1 \mathrm{~min}$, extension at $72^{\circ} \mathrm{C}$ for 2 min and a final extension for $7 \mathrm{~min}$ at $72^{\circ} \mathrm{C}$. PCR products of the isolates and reference strains were digested with restriction enzyme Alul (Laguerre et al., 1994). The restriction fragment length polymorphism (RFLP) patterns obtained from the digestion were observed with a Gel Documentation system. Similarity matrices were constructed and analyzed UPGMA cluster analysis using bio statistical analysis software NTSYS (Rohlf et al., 1998).

Sequence analysis: The PCR amplified products of $16 \mathrm{~S}$ rDNA gene were sequenced with 3500 Genetic Analyzer at Genomics and DNA Bar-coding Lab, Department of Biotechnology, Assam University. The quality of the sequence was assessed and edited by BioEdit program (Hall et al., 1999). The acquired sequences from this study, together with the related sequences obtained from GenBank with the BLAST program, were aligned by CLUSTAL W program (Thompson et al., 1994). Phylogenetic trees were constructed with MEGA 4.0 software package by neighbor-joining method (Tamura et al., 2007).

Nodulation: The nodulation capacity of the isolates was assessed in a greenhouse. Seeds were surface sterilized by gently rinsing in $70 \%$ ethanol for $2 \mathrm{~min}$ and $\mathrm{HgCl}_{2}$ for $3 \mathrm{~min}$. Three seeds of $M$. pudica were sown in one plastic pot containing vermiculite-quartz sand mixture and moistened with nitrogen free nutrient solution at regular intervals. Emerging seedlings were inoculated with a fresh suspension of bacterial strain. Uninoculated plants were included as control. The plants were harvested after 45 days of planting and observed for the presence and absence of nodules.

\section{Results and Discussion}

Twenty seven bacterial samples isolated from M. pudica root nodules were similar in morphological and microscopic characteristics, but showed wide variation in their biochemical features indicating the presence of diverse types of rhizobial strains. The isolates and reference strains showed white, creamy colonies on YEMA media and colony size of the isolates reached $0.8-1.0 \mathrm{~mm}$ in diameter after $3-5$ days of incubation at $28^{\circ} \mathrm{C}$. The isolates were Gram negative and rod in shape.

Based on their morphological, microscopic, biochemical features and comparison with known rhizobial reference strains ten probable rhizobial isolates were selected. Among the ten selected isolates, seven isolates viz. IMP1, HMP1, KMP1, BMP1, GMP1, NCMP1, DMP2 showed close similarity with reference strain B. cepacia MTCC 4684 in their biochemical features, they showed positive results of catalase, oxidase, nitrate, citrate, gelatin tests and negative results of ketolactose, urease, citrate test (Table 1). The remaining three isolates, SIMP1, KOMP2 and SMP2 showed no similarity with the reference strains in their biochemical features.

Soil pH and salinity plays an important role in limiting the growth of microorganisms in soil. The result of the present study showed that most of the isolates grew well at $\mathrm{pH} 6$ but showed variable growth at $\mathrm{pH} 5$ and were unable to grow at $\mathrm{pH} 4$. Similar findings on the isolation of acid tolerant Rhizobium strains from different cultivated legumes from lower Brahmaputra valley of Assam was reported by Choudhury et al. (2010). In the salinity tolerance test, the isolates showed no growth at $3 \% \mathrm{NaCl}$, at $2 \%$ $\mathrm{NaCl}$ few isolates survived and at $1 \% \mathrm{NaCl}$ all the isolates survived. Similarly in a previous study, Pandey et al. (2005) reported the presence of Burkholderia sp. in the root nodule of $M$. pudica that could effectively tolerate $1 \% \mathrm{NaCl}$. The results also indicated that the isolates which tolerated different stress condition \& (low pH/ high salinity) could be used as effective inoculants in future.

Plant growth promoting ability tests revealed that the selected isolates produced IAA, ammonia and solubilized inorganic phosphate. IAA is an important plant hormone and plays a significant role in plant growth. In the present study, except GMP1, all the isolates and reference strain produced IAA. The amount of IAA production varied greatly among the isolates, and the isolate HMP1 produced highest amount of IAA $\left(73 \mu \mathrm{gml}^{-1}\right)$ which was much higher than the amount of IAA produced by the reference strain $R$. leguminosarum $\left(45{\mu \mathrm{gm}^{-1}}^{-1}\right.$ ) (Table 2). Similar to the present study, Pandey et al. (2005) reported the production of IAA by rhizobia isolated from $M$. pudica. Phosphate solubilization efficiency of the isolates was determined by comparing the colony diameter of the isolates with the diameter of the solubilization zone.

Present study revealed that all the isolates were capable of phosphate solubilization and the isolate NCMP1 showed highest phosphate solubilization efficiency (161\%). Further, eight isolates were capable of producing ammonia (Table 2). Development of faint yellow to dark brown color on bacterial inoculated peptone broth indicated the production of ammonia. Similar to the present results, Bhargava et al., (2016) also reported the isolation of rhizobia from M. pudica plant which can solubilize inorganic phosphate and produce ammonia.

For determining nitrogen fixation ability of the isolates PCR amplification of nifH genes were carried out. nifH gene encodes Fe-protein subunit of nitrogenase enzyme, which is an important enzyme of biological nitrogen fixation pathway. Amplification result revealed that nifH gene was present in all the selected isolates confirming their ability to produce nitrogenase enzyme. A band at $360 \mathrm{bp}$ was amplified in nifH gene positive isolates (Fig 1). The presence of nifH gene in the root nodule 
Table 1: Biochemical features of selected isolates

\begin{tabular}{|c|c|c|c|c|c|c|c|c|c|c|}
\hline \multirow[t]{2}{*}{ Isolates } & \multirow{2}{*}{\multicolumn{2}{|c|}{ Site of collection }} & \multicolumn{8}{|c|}{ Biochemical features } \\
\hline & & & Ketolactose & Catalase & Oxidase & Nitrate & Starch & Urease & Citrate & Gelatin \\
\hline IMP1 & $\begin{array}{l}\text { Cachar } \\
\left(25.08^{\circ} \mathrm{N}-8\right.\end{array}$ & $\left.2.91^{\circ} \mathrm{E}\right)$ & - & + & + & + & - & - & + & + \\
\hline HMP 1 & Cachar & & - & + & + & + & - & - & + & + \\
\hline KMP 1 & $\begin{array}{l}\text { Karimganj } \\
\left(24.87^{\circ} \mathrm{N}-\mathrm{C}\right.\end{array}$ & $\left.2.35^{\circ} \mathrm{E}\right)$ & - & + & + & - & - & - & + & + \\
\hline BMP1 & Karimganj & & - & + & + & + & - & - & + & + \\
\hline SIMP 1 & $\begin{array}{l}\text { Hailakandi } \\
\left(24.68^{\circ} \mathrm{N}-\mathrm{c}\right.\end{array}$ & $\left.2.57^{\circ} \mathrm{E}\right)$ & - & + & + & - & - & - & - & - \\
\hline GMP 1 & Hailakandi & & - & + & + & + & - & - & + & + \\
\hline NCMP 1 & $\begin{array}{l}\text { N.C.Hills } \\
\left(25.18^{\circ} \mathrm{N}-\mathrm{c}\right.\end{array}$ & $\left.3.03^{\circ} \mathrm{E}\right)$ & - & + & + & + & - & - & + & + \\
\hline DMP 2 & N.C.Hills & & - & + & + & + & - & - & + & + \\
\hline KOMP2 & $\begin{array}{l}\text { Kamrup } \\
\left(26.20^{\circ} \mathrm{N}-\mathrm{g}\right.\end{array}$ & $\left.1.15^{\circ} \mathrm{E}\right)$ & - & + & + & + & - & + & - & - \\
\hline SMP 2 & $\begin{array}{l}\text { Tezpur } \\
\left(26.63^{\circ} \mathrm{N}-\mathrm{c}\right.\end{array}$ & $\left.2.8^{\circ} \mathrm{E}\right)$ & - & + & + & + & - & - & - & - \\
\hline R.leguminosarum & Reference & strain & - & + & + & - & - & + & - & - \\
\hline B. japonicum & Reference & strain & - & + & + & + & - & + & + & - \\
\hline M. thiogangeticum & Reference & strain & - & + & + & - & - & + & - & - \\
\hline B. cepacia & Reference & strain & - & + & + & + & - & - & + & + \\
\hline \multicolumn{11}{|c|}{$+=$ positive test result; $-=$ negative test result } \\
\hline \multirow[t]{2}{*}{ Isolate } & \multirow{2}{*}{\multicolumn{2}{|c|}{$\begin{array}{l}\text { IAA } \\
\left(\mu \mathrm{gll}^{-1}\right)\end{array}$}} & \multirow{2}{*}{$\begin{array}{l}\text { Ammonia } \\
\text { production }\end{array}$} & \multicolumn{3}{|c|}{ pH tolerance } & \multicolumn{3}{|c|}{ Salt tolerance } & \multirow[t]{2}{*}{ nifHgene } \\
\hline & & & & $\mathrm{pH} 4$ & $\mathrm{pH} 5$ & $\mathrm{pH} 6$ & $1 \%$ & $2 \%$ & $3 \%$ & \\
\hline IMP1 & 42 & 145 & + & - & - & + & + & + & - & $P$ \\
\hline HMP1 & 73 & 137 & + & - & + & + & + & - & - & $P$ \\
\hline KMP1 & 37 & 122 & + & - & + & + & + & - & - & $P$ \\
\hline BMP1 & 68 & 140 & - & - & + & + & + & - & - & $P$ \\
\hline SIMP1 & 55 & 126 & + & - & + & + & + & + & - & $P$ \\
\hline GMP1 & 00 & 148 & + & - & - & + & + & - & - & $P$ \\
\hline NCMP1 & 27 & 161 & - & - & - & + & + & + & - & $P$ \\
\hline DMP2 & 33 & 157 & + & - & - & + & + & + & - & $P$ \\
\hline KOMP2 & 40 & 152 & + & + & + & + & + & - & - & $P$ \\
\hline SMP2 & 65 & 138 & + & - & + & + & + & + & + & $P$ \\
\hline R.leguminosarum & 45 & 125 & + & - & - & + & + & - & - & $P$ \\
\hline
\end{tabular}

IAA = Indole acetic acid; PSE = Phosphate solubilization efficiency; + = Growth; - = No growth; $P=$ Presence of nifH gene

bacteria isolated from Mimosa pudica was previously reported by Mishra et al. (2012). Presence of nifH in all the selected isolates clearly indicated that the isolates were capable of synthesizing nitrogenase enzyme. Likewise, Klonowska et al. (2012) investigated the genetic diversity of Mimosa pudica rhizobial symbionts based on the phylogenetic analysis of nifH, nodA, $16 \mathrm{~S}$ rRNA and recA gene sequences.

RFLP analysis of $16 \mathrm{~S}$ rDNAgene is considered as a novel technique for studying genetic diversity of rhizobia (Laguerre et al., 1994). Characterization of rhizobial strains based on $16 \mathrm{~S}$
rDNA PCR-RFLP analysis has previously been reported in many studies. Pandey et al. (2004) isolated and characterized rhizobia from five different medicinal legumes based on $16 \mathrm{~S}$ rDNA PCRRFLP analysis using two restriction enzymes Haelll and Mspl. Chen et al. (2003) reported the characterization of bacterial strains isolated from root nodules of legume plants belonging to Mimosa genera, including Mimosa pudica based on their 16S rDNA PCR-RFLP analysis. Result of RFLP analysis revealed diverse banding pattern of the isolates and reference strains (Fig 2). The gel image clearly revealed the presence of distinct DNA bands which ranges from $100 \mathrm{bp}$ to $700 \mathrm{bp}$. Restriction pattern 


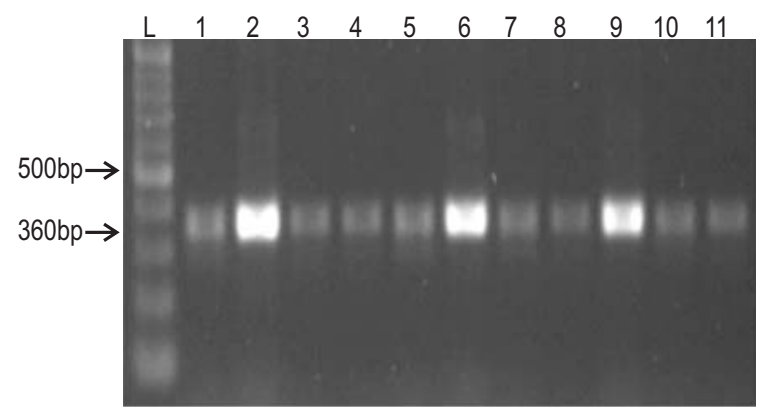

Fig. 1 : nifH gene amplification on 1.5\% agarose gel. Lanes : L. Ladder, 1. BMP1, 2. SMP2, 3. KOMP2, 4. KMP1, 5. GMP1, 6. DMP2, 7. NCMP1, 8. IMP1, 9. SIMP1, 10. HMP1, 11. R.leguminosarum

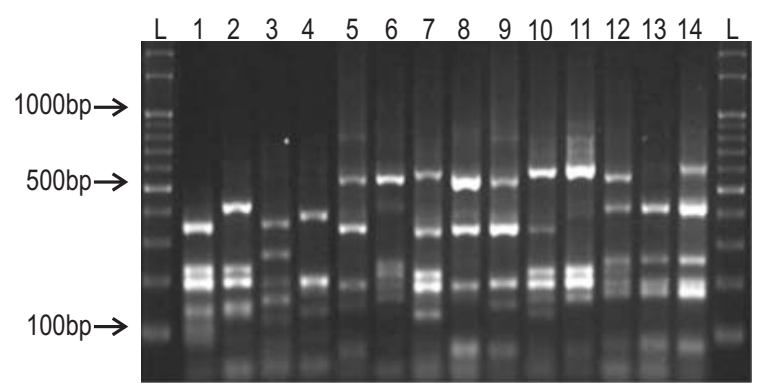

Fig. 2 : PCR-RFLP profile on $2 \%$ agarose gel. Lanes : L. Ladder, 1. BMP1, 2. SMP2, 3. KOMP2, 4. KMP1, 5. GMP1, 6. DMP2, 7. NCMP1, 8. IMP1, 9. SIMP1, 10. HMP1, 11. B. cepacia, 12. M. thiogangeticum, 13. R. leguminosarum, 14. B. japonicum

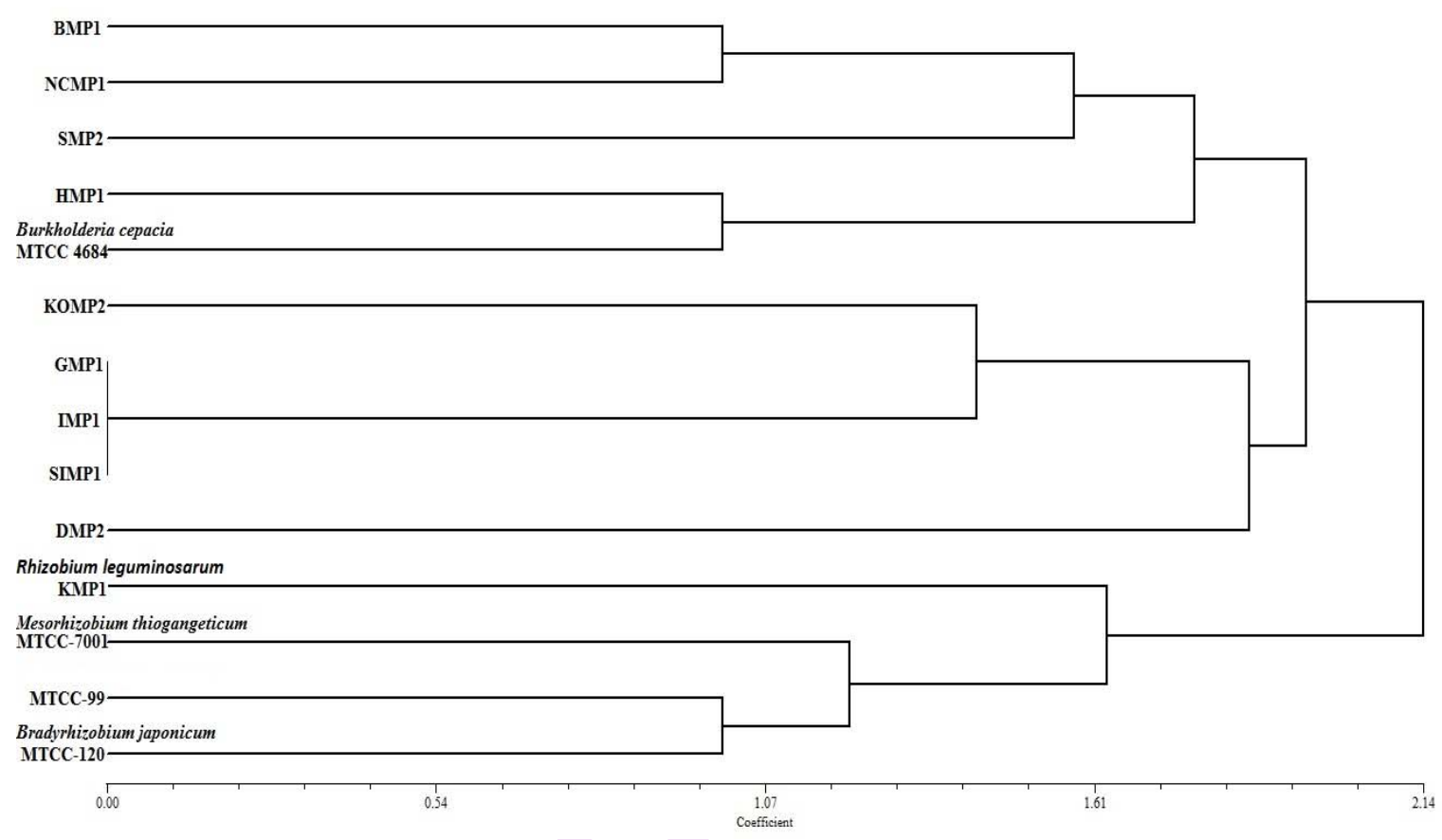

Fig. 3 : Unweighted Pair Group Method with Arithmetic mean (UPGMA) dendrogram based on RFLP analysis of isolates and reference strains

obtained from electrophoresis were used to construct an UPGMA tree by NTSys software.

UPGMA dendrogram analysis grouped the isolates into three different clusters. Cluster 1 comprised of four isolates BMP1, NCMP1, SMP2, HMP1 and reference strain B. cepacia. Cluster 2 comprised of five isolates KOMP2, GMP1, IMP1, SIMP1 and DMP2. Cluster 3 comprised of one isolates KMP1 and reference strains $M$. thiogangeticum, $R$. leguminosarum and $B$. japonicum. The considerable diversity observed among the RFLP pattern of isolates indicates that the isolates were significantly diverse.
In the present study, four isolates of M. pudica (SMP2, HMP1, DMP2 and KMP1) representing three clusters of PCRRFLP analysis were selected for $16 \mathrm{~S}$ rDNA gene sequencing. NCBI-BLAST analysis of the sequences revealed that SMP2, HMP1 and DMP2 were closely related to Burkholderia mimosarum PAS44 (NR_752958). B. mimosarum was first reported by Chen et al., (2006) from the root nodules of Mimosa pigra and Miomosa scabrella from Taiwan, Venezuella and Brazil. In a previous study, Gehlot et al., (2013) also reported the symbiotic association of $B$. mimosarum with root nodules of $M$. pudica plants from different geographical locations of Assam and 


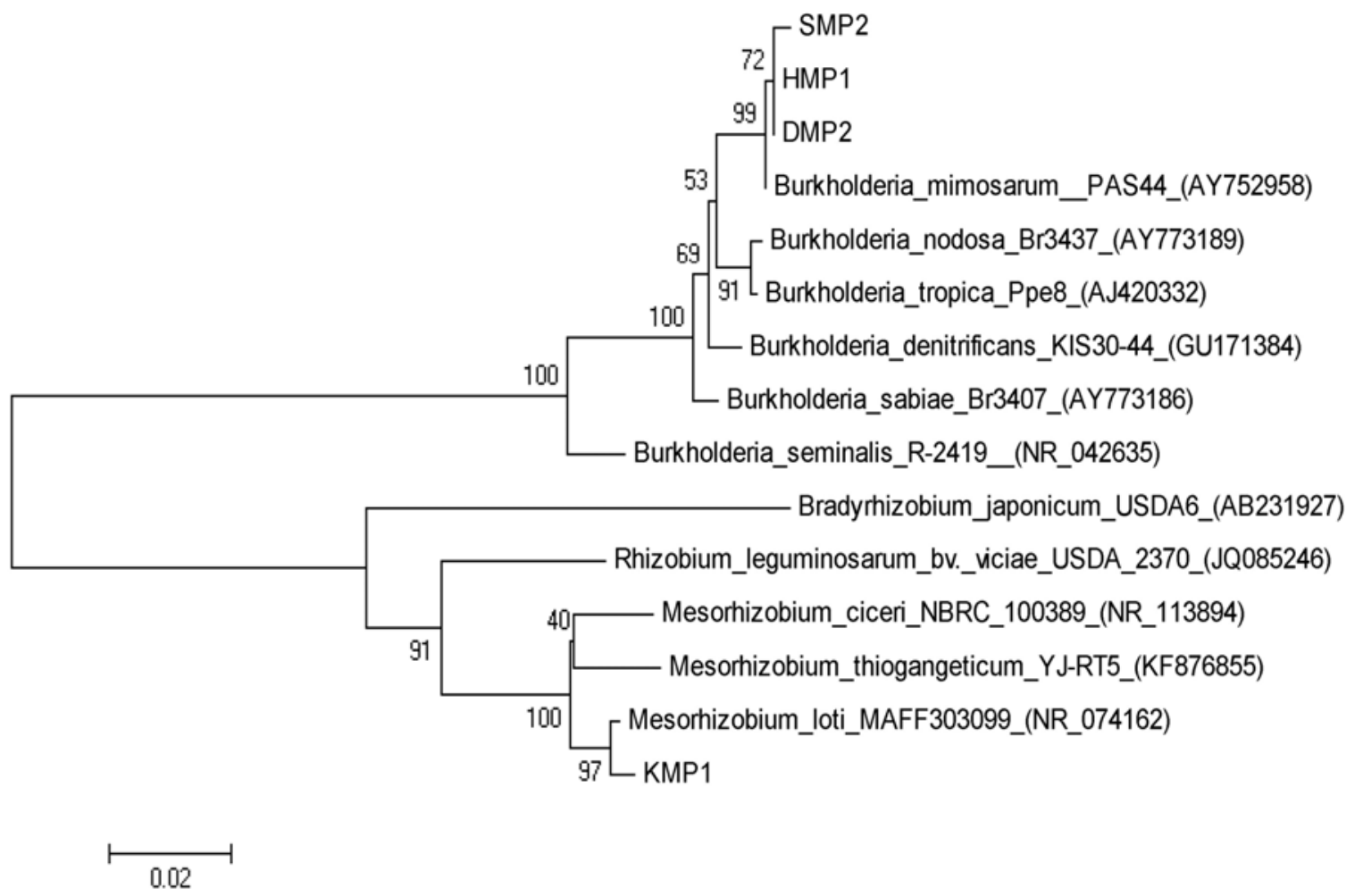

Fig. 4 : Phylogenetic (neighbor-joining) tree depicting the relationship of four isolates and reference strains from NCBI database. Species name are followed by their Gen-bank accession numbers. The numbers shown next to each bifurcation are bootstrap percent values based on 1000 replications

Meghalaya. The result of $16 \mathrm{~S}$ rDNA gene sequencing clearly indicated that beta-rhizobia belonging to genus Burkholderia were the most common symbiont of M. pudica. Several studies have previously reported that species belonging to Burkholderia and Cupriavidus genera were the most common symbionts of $M$. pudica, however in the present study no strains from Cupravidus genera were characterized (Chen et al., 2003; Liu et al., 2011). The isolate KMP1 showed closest similarity with Mesorhizobium loti MAFF303099 (NR_074162) which belongs to alpha rhizobia. Although beta-rhizobia appeared to be the predominant symbionts of $M$. pudica, the presence of alpha-rhizobia in close association with $M$. pudica had previously been reported by Barrett and Parker (2005). The acquired 16S rDNA sequences of four isolates were deposited in GenBank database and the strains were named as Burkholderia mimosarum SMP2 (GenBank accession no.-KJ_939616), Burkholderia mimosarum HMP1 (GenBank accession no.- KJ_939618), Burkholderia mimosarum DMP2 (GenBank accession no.- KJ_939619) and Mesorhizobium lotiKMP1 (GenBank accession no.-KJ_939617), respectively.

For determining nodule forming ability of isolated strains, seeds of $M$. pudica plants were treated with four selected isolates (SMP2 HMP1, DMP2, KMP1) and grown in pots containing sterile soil. In a previous study, Liu et al., (2011) reported that bacterial strains affiliated to Burkholderia, Cuprivadus and Rhizobia genera, isolated from Mimosa spp. can successfully form root nodules on their host plants. In agreement to the previous study, our investigation also reveals that the selected isolates can effectively form nodules in the root of original host plant M. pudica. The nodules were healthy, pink in color and the number of nodules varied from $10-15$ per plant.

Thus in conclusion it can be said that, the present study provide new information about the phenotypic and genotypic diversity of indigenous rhizobia associated with Mimosa pudica grown in Assam. We found that bacterial strains belonging to the genera Burkholderia were the predominant symbionts of Mimosa pudica. The positive results of plant growth promoting activities, stress tolerant activities and the presence of nifH gene in the isolates indicated their active role in plant growth promotion. In future the indigenous isolates could be used as effective inoculants for sustainable agriculture development.

\section{Acknowledgment}

The authors are thankful to the Department of Biotechnology (DBT), Government of India for financial support under Major Research Project. 


\section{References}

Ahmad, H., S. Sehgal, A. Mishra and R. Gupta: Mimosa pudica L. (Laajvanti): An overview. Pharmacogn . Rev., 6, 115-124 (2012).

Barrett, C.F. and M.A. Parker: Prevalence of Burkholderia sp. nodule symbionts on four mimosoid legumes from Barro Colorado Island, Panama. Syst. Appl. Microbiol., 28, 57-65 (2005).

Bhargava, Y., J.S.R. Murthy, T.V.R. Kumar and M.N. Rao: Phenotypic, stress tolerance and plant growth promoting characteristics of rhizobial isolates from selected wild legumes of semiarid region, Tirupati, India. Adv. Microbiol., 6, 1-12 (2016)

Chen, W.M., E.K. James, T. Coenye, J.H. Chou, E. Barrios, S.M. Faria, G.N. Elliott, S.Y. Sheu, J.I. Sprent and P. Vandamme: Burkholderia mimosarum sp. nov., isolated from root nodules of Mimosa spp. from Taiwan and South America. Int. J. Syst. Evol. Micr., 56,1847-1851 (2006).

Chen, W.M., S. Laevens, T.M. Lee, T. Coenye, P. deVos, M. Mergeay and P. Vandamme: Ralstonia taiwanensi ssp. nov., isolated from root nodules of Mimosa species and sputum of a cystic fibrosis patient. Int. J. Syst. Evolut. Microbiol., 51,1729-1735 (2001).

Chen, W.M., L. Moulin, C. Bontemps, P. Vandamme, G. Bena and M.C. Boivin: Legume symbiotic nitrogen fixation by beta-proteobacteria is widespread in nature. J. Bacteriol., 185, 7266-7272 (2003).

Choudhury, B., P. Azad and M.C. Kalita: Variability in symbiotic effectiveness of native rhizobia in acid stress. Curr. Microbiol., 61, 85-91 (2010).

Deshwal, V.K., R.C. Dubey and D.K. Maheshwari: Isolation of plant growth promoting strains of Bradyrhizobium (Arachis sp.) with biocontrol potential against Macrophomina causing charcoal rot of peanut. Curr. Sci., 84, 443-448 (2003).

Dilworth, M.J. and C.A. Parker: Development of the nitrogen fixing system in legumes. J. Theor. Biol., 25, 208-218 (1969).

Dubey, R.C., D.K. Maheshwari, H. Kumar and K. Choure: Assessment of diversity and plant growth promoting attributes of rhizobia isolated from Cajanus cajan L. Afr. J. Biotechnol., 9, 8619-8629 (2010)

Gehlot, H.S., N. Tak, M. Kaushik, S. Mitra, W.M. Chen, N. Poweleit, D. Panwar, N. Poonar, R. Parihar, A. Tak, I.S. Sankhla, A. Ojha, S.R. Rao, M.F. Simon, F.B.R. Junior, N. Perigolo, A.K. Tripathi, J.I. Sprent, J.P.W. Young, E.K. James and G. Prasad: An invasive Mimosa in India does not adopt the symbionts of its native relatives. Ann. Bot., 112, 179-196 (2013)

Gordon, S.A. and R.P. Weber: Colorimeteric estimation of indole acetic acid. Plant. Physiol., 26, 192-195 (1951)

Hall, T.A.: BioEdit: A user friendly biological sequence alignment editor and analysis program for Windows 95/98/NT. Nucleic. Acids. Symp. Ser., 41, 95-98 (1999).

Holt, J.G., N.R. Krieg, P.H.A. Sneath, J.T. Staley and S.T. Williams: In: Bergey's Manual of Determinative Bacteriology. Williams and Wilkins Press, Baltimore, U.S.A. (1994).

Klonowska, A., C. Chaintreuil, P. Tisseyre, L. Miche, R. Melkonian, M. Ducousso, G. Laguerre, B. Brunel and L. Moulin: Biodiversity of Mimosa pudica rhizobial symbionts (Cupriavidus taiwanensis, Rhizobium mesoamericanum) in New Caledonia and their adaptation to heavy metal-rich soils. FEMS. Microbiol. Ecol., 81, 618-635 (2012).

Kucuk, C., M. Kivanc and E. Kinaci: Characterization of Rhizobium sp. isolated from bean. Turk. J. Biol., 30,127-132 (2006).

KumarA., S. Devi, S. Patil, C. Payal and S. Negi: Isolation, screening and characterization of bacteria from rhizospheric soils for different plant growth promotion (PGP) activities: An in vitro study. Rec. Res. Sci. Tech., 4, 01-05 (2012)

Laguerre, G., M.R. Allard, F. Revoy and N. Amarger: Rapid identification of rhizobia by restriction fragment length polymorphism analysis of PCR-amplified 16S rRNA genes. Appl. Environ. Microbiol., 60, 56-63 (1994).

Liu, X.Y., W. Wu, E.T. Wang, B. Zhang, J. Macdermott and W.X. Chen: Phylogenetic relationships and diversity of b-rhizobia associated with Mimosa species grown in Sishuangbanna China. Int. J. Syst. Evol. Microbiol., 61, 334-342 (2011).

Liu, X.Y., S. Wei, F. Wang, E.K. James, X.Y. Guo, C. Zagar, L.G. Xia, X. Dong and Y. P. Wang: Burkholderia and Cupriavidus spp. are the preferred symbionts of Mimosa spp. in Southern China. FEMS Microbiol. Ecol., 80, 417-426 (2012).

Mishra, R.P.N., P. Tisseyre, R. Melkonian, C. Chaintreuil, L. Miche, A. Klonowska, S. Gonzalez, G. Bena, G. Laguerre and L. Moulin: Genetic diversity of Mimosa pudica rhizobial symbionts in soils of French Guiana: investigating the origin and diversity of Burkholderia phymatum and other beta-rhizobia. FEMS. Microbiol. Ecol., 79, 487-503 (2012).

Pandey, P., M. Sahgal, D.K. Maheswari and B.N. Johri: Genetic diversity of rhizobia isolated from medicinal legumes growing in the subHimalayan region of Uttaranchal. Curr. Sci., 86, 202-207 (2004).

Pandey, P., S.C. Kang and D.K. Maheshwari: Isolation of endophytic plant growth promoting Burkholderia sp. MSSP from root nodules of Mimosa pudica. Curr. Sci., 89,177-180 (2005).

Pikovskaya, R.I.: Mobilization of phosphorous in soil in connection with vital activity of some microbial species. Microbiologiya, 17, 362370 (1948).

Rohlf, F.J.: NTSYS-PC: Numerical taxonomy and multivariate analysis system version 2.02f, Exeter Software, Setauket, New York, USA, (1998).

Romdhane, S., H. Nasr, M.R. Samba, M. Neyra, M.H. Ghorbel and P.D. Lajudie: Genetic diversity of Acacia tortilis $\mathrm{sp}$. raddiana rhizobia in Tunisia assessed by $16 \mathrm{~S}$ and $16 \mathrm{~S}-23 \mathrm{~S}$ rDNA genes analysis. $\mathrm{J}$. Appl. Microbiol., 100, 436-445 (2006).

Sambrook, J., E.F. Fritsch and T. Maniatis: Molecular cloning: A laboratory manual. Cold Spring Harbor, New York (1989).

Tamura, K., J. Dudleym, M. Nei and S. Kumar: MEGA4: Molecular Evolutionary Genetics Analysis (MEGA) software version 4.0. Mol. Biol. Evol., 24, 1596-1599 (2007).

Thompson, J.D., D.G. Higgins and T.J. Gibson: CLUSTAL W: Improving the sensitivity of progressive multiple sequence. Nucleic. Acids. Res., 22, 4673-4680 (1994).

Vincent, J.M.: A Manual for the Practical Study of the Root-Nodule Bacteria. Oxford: Blackwell Scientific (1970).

Weisburg, W.G., S.M. Barns, D.A. Pelletier and D.J. Lane: 16 S ribosomal DNA amplification for phylogenetic study. J. Bacteriol., 173, 697-703 (1991).

Zehr, J.P. and L.A. McReynolds: Use of degenerate oligonucleotides for amplification of the nifH gene from the marine cyanobacterium Trichodesmium thiebautii. Appl. Environ. Microb., 55, 2522-2526 (1989). 